\title{
TRAUMA AND THE VICTIM ECONOMY
}

\author{
Sergey Troitskiy \\ Senior Research Fellow \\ Herzen State Pedagogical University of Russia \\ sergtroy@yandex.ru
}

\begin{abstract}
The history of the twentieth century is filled with examples of mass murder and destruction of entire nations. Survivors of those traumatic events have horrific memories, which cannot be compared to anything that may happen in the course of an ordinary quiet life. However, coping strategies for overcoming the consequences of such traumatic experience were also developed in the twentieth century. It was made possible by conceptualisation of trauma as a cultural and psychological phenomenon at the level of theory and practice in various sciences. Introduction of this concept into the flesh and blood of modern (popular) culture, or rather its inclusion in the fabric of everyday cultural practices, transformed the concept of trauma into a mechanism of culture. Trauma developed into a concept, as we know it, because it functioned as one of the cultural clichés of the era, according to which economics, politics, science, literature, etc., are built. Of course, mass exterminations of people took place even before the twentieth century; however, they were not interpreted as historical traumas as we interpret them now because, firstly, a sense of distance from the event was not developed, which is characteristic of traumatic interpretation, and, secondly, the narratives corresponded to other cultural clichés (typical of those epochs), which served as the basis for political mechanics, economic processes, etc. This article identifies the main features characterising the functioning of trauma as a cultural mechanism. This objective is achieved by appealing to political economy and Baudrillard's and Derrida's critique of the victim order. In this study the term "loss" is used as an umbrella term for various traumatic constructs, such as the victim and the trauma itself. They are characterised as objects of a credit relationship between subjects (both individual and collective), according to which the victim (trauma) construct could be described as a debt obligation that must be fulfilled by paying off a symbolic debt. The study identifies all the acting forces (parties) in the trauma construct, which give form to this construct. The author draws attention to the spatial (topographical) accent of the traumatic narrative, as well as to the necessity of toponymic localisation of the active forces in space.
\end{abstract}

Keywords: construct, cultural memory, forgiveness, Jacques Derrida, Jean Baudrillard, localisation, political economy, referee, sacrifice, third party, topography, tormentor, trauma, victim, victim economy, victim order 
We even evaluate death in terms of interest rates, in value-for-money terms. An economic calculation that is a poor man's calculation - poor men who no longer even have the courage to pay the price.

(Baudrillard 2003: 25)

\section{INTRODUCTION}

The study of cultural exclusion zones (Chertenko \& Nikolaeva \& Troitskiy 2018) in relation to traumatic experience faces the essential requirement to define the principal elements that make up that experience, i.e., to reveal the structure in which the memory of a trauma forgets (displaces) the experience itself and replaces it with a narrative model. At the same time, the trauma narrative is itself the product of a construction of linguistic and cultural clichés (Oushakine 2009), a "matrix text", ${ }^{1}$ as a result of which its social (collective) nature becomes evident; therefore, any individual trauma narrative transforms easily into a narrative of collective trauma (Resende \& Budryte 2014; Vignoles et al. 2006; Hirschberger 2018; etc.). However, collective trauma, as the constructed experience of a social group, which gathers the group together into a unified body as the subject of trauma and furnishes that group with a stable identity, can also dictate the relationship model for other social groups with the first group as the subject of trauma.

Manifestations of collective memory have precedence over the individual one, they are "especially important, more important than individual memory, because collective memory strictly censors individual one" (Niethammer 2014). Collective memory is constructed in the process of transindividual and transactive communication as a dominant idea and pattern of mental feelings and subjective behaviour. The content of collective memory is the object of (pseudo) remembering but not by the subject of memorial experience; that is why the content exists as a complex of stereotypical elements. According to Halbwachs, "in each epoch [memory] reconstruct[s] an image of the past which is in accord ... with the predominant thoughts of the society" (Halbwachs 1992: 40). Subjects of the collective memory are separate persons who are often widely dispersed and not related to each other, like members of a nation or citizens of a state (Barash 2017; Olick \& Vinitzky-Seroussi \& Levy 2011), because "collective memory is inextricably connected with power relations and the notion of an 'identity politics"' (Tan 2020: 3). Some scholars find mechanisms of collective memory in a small group of the nearest and dearest, e.g., a family (Hirst $\&$ Echterhoff 2008; Stone et al. 2012). However, both large-scale and small-scale 
groups are characterized by patternality, transpersonality, and constructivity (Arango-Muñoz \& Michaelian 2020; Tan 2020).

This symbolic localization of trauma also defines the topographical (physical) localization of trauma in the person of the collective subject of that trauma. A great deal has been written about the individual experience of collective trauma from the standpoint of psychology, psychiatry, and psychoanalysis, beginning with the classic works by Cathy Caruth, Dominick LaCapra, Jeffrey Alexander, and others (Caruth 1995; LaCapra 1994; Alexander et al. 2004). There are a significant number of reviews on trauma studies, one of the most recent ones is the review by Alexey Sidorov (Sidorov 2020; Kidron 2003). However, here we are less interested in this subjective aspect of cultural traumatology than in the mechanisms behind the transfer of individual traumatic memory experience into the political and social space by means of political economics. ${ }^{2}$ What is the relationship model between a subject of collective trauma and the remaining groups in society? To what extent are the mechanisms of memory and economics linked? These questions will be the focus of this article. The impetus for these deliberations was provided by French philosophers Jacques Derrida (Derrida 2000; 2001) and Jean Baudrillard (Baudrillard 1996; 2003), and in its own way this article develops their ideas further. During my work on this paper, I also came across the short story "Bronek" by Polish writer Magdalena Tulli, from her book Wtoskie szpilki (Italian High Heels) (Tulli 2011), where the author depicts characters who have undergone a traumatic experience. Since her artistic intuition coincides with my own thinking, I will make references to this text as a supplementary source of concisely formulated propositions.

\section{THE SPACE AND TIME OF TRAUMA}

The mental reconstruction of trauma enables the researcher to elicit those elements which are inextricably linked by the subject in the actual experience of trauma, but which readily lend themselves to thorough and detailed examination during the investigative process. Investigative strategies enable a separate examination of the traumatic act, the traumatic experience in terms of its significance in the memory, the subject of the trauma, the associate subject to the trauma (the quasi-subject of the trauma), the quasi-memory of (someone else's) trauma, and many other functional elements. Such a delineation allows cultural traumatology to more effectively do its work, to unravel the tangle of contradictions between the actual event and the memory of it, between the subjective and objective levels of the trauma's existence, and so on. 
As has been shown by the research of Sergei Oushakine and Elena Trubina (2009), a traumatic act (event) itself is not temporal in nature for the subject of the trauma. At the moment of its perpetration, a traumatic act is experienced as another of those physical sensations which make up daily life. Jean Baudrillard notices it when he describes Bosnians' reactions of compassion among the French (and generally, European) people in the period of the Bosnian War (Baudrillard 1996: 131-141). The actuality of the experience makes the reality of a traumatic subject and their own local world hyper-real, but the inclusion of the traumatic subject into this hyper-reality is not interpreted as traumatic. Even when considering the intensity and painfulness of this sensation or its numerous repetitions, the experience is granted its traumatic nature by the very memory processes by which the subject endeavours to return to it or to displace it. This mental activity in relation to traumatic experience makes it constantly real, switching it on into a regime of deferred action. Traumatic experience as an image of the traumatic act produced in the subject's memory does have temporal characteristics, which are set by the memory, or rather by the limitations of its workings. These limitations are principally narrative in nature, since the remembering (recollection) of the traumatic experience (traumatic act) is structured as a narrative account of it. "The narrator creates history anew by his narration; he models his past according to any political and cultural foundations, specificity of his own biography, mental attitude. It is also necessary to consider the changeability of his personal attitude to events" (Artemenko 2020: 62). Furthermore, speaking about personal trauma is only possible in retrospect and post factum. A literature example of a retrospective recollection of a traumatic event is the short story "Bronek" (Tulli 2011), in which an old woman, the narrator's mother, consistently returns to the moment of the most intense experience. She tries to get to the pre-traumatic stage of her personal history, i.e., before the beginning of the Second World War. It is not remembrance but imagining oneself in the real concrete time and events. The narration looks like a classical medical history of memory disintegration at the late age. However, the author can show mechanisms behind the retrospective existence of the image of trauma with its main markers, personalities, and topoi, because the character holds hidden and untold traumatic experience as the most emotional one in her life, and her memory returns into it at the expense of the present-day memory.

Another way of talking about trauma is talking about someone else's trauma because "those ... at the very heart of war and distress, do not really believe in it" (Baudrillard 1996: 133). The exclusion of the subject from the activity, the reality, the event makes them unable to talk about the traumatic experience 
as a (hi)story, to make it a plot of narration, because the listener is not able to understand a real history, "to share it" (Lekhtsier 2018: 122), i.e., to hear the story that the traumatised speaker tries to tell (Jackson 2007; Butler 1992; Mould 2011). The loss of narrative quality (fragmentation, pauses, repetitions, etc.) is caused by the need to convey all external and internal connections, accents, and meanings that make the story real and convey the specificity of the situation. The inability to "manage" the story and convey real experience forces the speaker to be "either stubbornly silent or disturbingly voluble" (Willsey 2015: 217). There are strategies for post-traumatic stress disorder (PTSD) patients in the USA and other countries for managing the narrative and learning to talk about traumatic experience. This is construed as "as a panacea for national wounds" and is aimed at ensuring that the subject could make a certain "performance" of the story in every particular case, keeping in mind a specific audience and context (Willsey 2015). This approach allows transforming a remembered experience into a beam of stories (like a beam of light), where each of them is incomplete when taken separately and represents a limited image of a traumatic event using a complex of communicative and narrative clichés. The development of the subject's skills to tell the (hi)story of a personal trauma allows the subject to look at the trauma anew and fix its image(s). Therefore, it allows the subject to form an image of oneself (an identity), of someone who survived a traumatic experience, and it makes the memory of a trauma more operable and controlled because the traumatic experience has been deprived of a status of the "real" one and replaced with its image.

A typical narrative practice emerges from the coincidence of time and place in the chronotope of storytelling, but such a chronotope does not work with traumatic experience, and still less with a traumatic act. A traumatic act has no subjective duration, and nor does traumatic experience - memory can only repeat it. The excessive intensity of the traumatic act transforms time itself into a physical density (a dense physical substance) which can only be "spread out" through memory and narration. The act of narration (recollection) enables the time of the traumatic act (traumatic experience) to be put into sequence.

On the other hand, the ordeal intensity of the traumatic act, in assuming a material solidity, facilitates the identification of spatial elements in the trauma itself. The only irrefutable aspect of a traumatic experience (traumatic act) is in its committal, which secures the trauma as being factual. This committal may be reflected in physical marks or traces (Savchuk 2020: 120-121), which serve as markers of the experience for the subject, triggering the mechanism of forgetting/ remembering. The spatial nature of the traumatic experience along with the significance of markers for it give a factological character to the toponyms of trauma. 
In this sense, even at the objective level, traumatic toponyms are much more factographic than temporal markers: Katyn, Solovki, Babi Yar, Auschwitz, Majdanek - these are precise indicators of traumatic experience. Traumatic toponyms endow trauma with a concrete solidity, enabling the expansion from other traumatic experiences (and from the traumatic experiences of other subjects on the subjective level). For the subject of trauma, a toponymic marker makes their own traumatic experience into a way to self-identify and also allows them to translate this experience into a regime of comparison.

A literary example of the predominance of topography over chronology can be found in the short story "Bronek" (Tulli 2011) mentioned earlier. All traumatic experiences are distributed into concrete topoi, like a character's memory clusters, although the sequence of the traumatic events is not clear. The reader should guess it using the reverse chronological order of the return into the past that is unfolding throughout the story.

\section{CONFIGURATIONS OF LOSS}

The narrative nature of recollection compels traumatic experience to reveal itself through linguistic stamps and clichés. The palpable content of a traumatic act transforms into a narrative about the act as a result of the fact that a multitude of ways to talk about suffering have agglomerated in language, putting a name to it, and at the same time retrospectively constructing the traumatic experience itself.

With respect to the constructive character of experience, we can identify at a minimum of two modifications (two configurations) of it, which are embedded in the configuration of re-telling traumatic experience. For this reason, I have proposed elsewhere to define the construct of traumatic experience in its broadest aspect, using the term "loss", and the two differentiating configurations of loss using the term "sacrifice" and, indeed, "trauma" (Troitskiy 2017, 2019). Within this differentiation, sacrifice is the loss that is perceived by the subject to be final and irrevocable (Kapelchuk 2016: 148). In contrast to sacrifice, trauma implies redress for the loss (revenge, compensation, swapping to the opposite role, i.e., from the role of victim to the role of tormentor), ${ }^{3}$ deferred in time. Aleida Assmann introduces similar subjects of traumatic experience. She offers a "clear distinction between passive sacrifice and heroic martyr victim". According to Assmann, the sense of passive sacrifice "consists in its absolute passivity, connoted with innocence and purity" (Assmann 2006: 80). The antifascist post-war Soviet discourse, for example, was based on the image of martyr 
victim (subject of the loss-trauma). The word "fascists" was used as a name for the worst scoundrels and enemies with a connotation of atrocities against the victims. "The commemoration of children-martyrs who consciously sacrificed themselves to the enemy becomes crucial in the formation of the Great Patriotic War cult after 1945", Svetlana Maslinskaia writes in her research on the Soviet children's traumatic experience in the war literature of 1941-1945 (Maslinskaia 2019: 197). The martyr-victim image in literature and journalism was used to evoke necessary emotions in people, justifying aggression against the invader and legitimising war as a way of compensation for loss-trauma.

By way of example, we can take a situation familiar to us all. The act of extracting a tooth may well not turn into a traumatic experience or an element of trauma in the individual's memory complex. However, if the procedure of tooth extraction is being performed by a convicted sadist doctor, then the probability of the situation becoming traumatic is significantly increased. These two acts may not differ from one another intrinsically, but the subsequent memory construction, using stereotypes, political and juridical constructions, leads to the procedure performed in a comfortable dentist's surgery being radically different from the same procedure performed in a death camp. With this, I am slightly lumping the two situations together, but my intent is to show that the configuration of the construct of loss lies not in the traumatic experience (nor does it lie in the act of loss), but in the practice of recall. Even if the lost tooth is interpreted as a loss, then in the former case it is interpreted as a sacrifice, and in the latter as a trauma.

\section{THE VICTIM ECONOMY}

Both configurations of loss appear in the conceptual field of economics, or to be more precise, the field of political economics. The symbolic space of relationships based on goods and money is one of the ways in which a person thinks in terms of the subject-object relationship as a whole, along with the relationship between people and things, and people and people. For this reason, this form of interpretation of relationships also applies to subjective experience. The alienation of meaning in money applies also to traumatic experience and the experience of loss. By no means are we talking about the monetisation of trauma here, but merely about the means by which loss is imagined in culture, and more precisely, about how the constructs of trauma take on a transactional character. In this perspective, the victim becomes the transacted payment or loss (Giglioli 2014), and the trauma becomes the debt, deferred in time. ${ }^{4}$ Only 
then do the factuality and concreteness of the markers of traumatic experience grant precision to the deferred settlements for the debts of the trauma. The debt of the trauma is deferred in time.

In the short story "Bronek" (Tulli 2011), the author actualizes the idea of the conversion of traumatic experience in the field of political economy in a surprisingly precise and accurate way:

War, like the estate of a bankrupt, becomes the property of the generations that follow.

Participation in great battles, for instance, is like an inheritance. It is not so easy for grandchildren to separate themselves from it. They received their share of the interest from the battle of Stalingrad, or Kursk, say, while someone else may end up with a few vignettes from the streetfighting in Berlin - disparate, indistinguishable fragments. By law they also inherit their eye-colour, surname, and language, alas along with all the other attendant consequences, the least troublesome of which are tales from the front, re-told over several generations in the quiet of their homes. Best not to remember the worst parts. It is difficult to say which is better - phobia or mania, or which of these two strategies is best to recommend to descendants. Those who have inherited a tiny share of some kind of battle may well think that they are the lucky ones. It could be worse. The humiliations brought home from war in place of watches, picturesque canvases and other trophies lie frozen in storage for decades, accruing miserly interest... (Tulli 2011: 63-64)

I suggest calling such a political-economic interpretation of loss (trauma, sacrifice) the victim economy. This term incorporates both starting points - the political economy, and Baudrillard's description of contemporary reality as the victim society.

The debt obligations of trauma with deferred redress turn out to be an important basis for the construction of the collective body (Brodsky 2020). The overall debt, the overall loss with possible deferred redress enables the political manipulation of the wronged social whole through ideology, revisionist sentiments, and the idea of retribution (revenge). Within the collective body, the victim economy replaces moral law for its subjects, and on a subjective level provides unity and stability of the identity model. Stability and unity are formed from the homogeneity of the content of a trauma's quasi-memory (the traumatic quasi-experience), constructed with the aid of a system of narrative clichés, which are built up in compliance with the internal algorithm of the specific traumatic discourse. 
The experience of world war, be it the first or the second, has allowed the victim economy to spread across the entire world. Traumatic experience has also been conferred by local wars, but it was precisely the world war that created the basis for the globalisation of traumatic experience. The general traumatic experience endured required no description, only markers, which became the basis for the conversion of local experiences and the transfer of meanings disclosed through traumatic discourse. This commonality of discourse has become the foundation for the composition of trauma studies.

The victim economy is enshrined in the language of the authority (political and legal discourse). Baudrillard described this as a 'rights-on' category: "the right to pure air substitutes for asphyxia, the right to freedom for the exercise of freedom, or right itself for desire in the form of the right to desire, and so on. Rights are what mobilize the energies of an enervated social body" (Baudrillard 1996: 138). A "right" in the victim economy is a registration of anything borrowed with deferred compensation.

\section{CONFIGURATIONS OF THE SUBJECTS OF THE VICTIM ECONOMY AND THE CONFIGURATION OF TOPOLOGY}

Insofar as there exists a subject (whether individual or collective), which awaits recompense for its loss through promissory traumatic circumstances, there is also assumed to be a subject who is the presumed debtor. In the discourse of trauma, the former is the victim, and the latter is the tormentor. Moreover, such a classification can only be constructed retrospectively (a session of psychoanalysis, or a diary), but in the situation "which exists as it is - the reality of an action and a destiny" (Baudrillard 1996: 133), in the situation of Dasein (here and now), the possibility to assign roles to the subjects of the traumatic experience may not be available. ${ }^{5}$ However, alongside the "victimal" roles of the victim and the tormentor there is also a third party, acting in the role of a judge, which legitimises the other two. However, it may seem to us that in economics there is a debtor and a creditor, and it is clear who owes whom, and when it comes to the victim economy, both the victim and the tormentor act as opposite poles in relation to this third party, whose positive victim balance is maintained by the negative victim balance of the victim and the tormentor. The traumatic experience is the source of symbolic capital for this third party, and not for the victim. The moral subject can reveal itself as such only in relation to someone else (sympathy for the victim) or in comparison with something else (condemnation of the tormentor). What is more, the tormentor, as an 
ethically negative subject, and the victim as the trauma creditor, the subject of loss, both appear in relation to the third party in the position of subjects with a negative victim balance, creating a possibility to receive dividends from the loss (trauma); i.e., to provide a positive victim balance to the third party, since a positive subject cannot exist without a negative counterpart (the economics maxim fixed in the well-known phrase "one man's loss is another man's gain"). Baudrillard notes that "[a]ll these 'corridors' we open up to send them our supplies and our 'culture' are, in reality, corridors of distress through which we import their force and the energy of their misfortune" (Baudrillard 1996: 134). In this regard, the construction of an external victim and tormentor is a good way to gain preference and pay off the debt. The victim's image is constructed by portraying the subject as a victim, by allocating compassion to the subject. "Only in the hollow form of the victim we today find a plausible image, even if reversed, of the fullness to which we aspire, a 'mythological machine' that, starting from the empty centre of a lack, incessantly generates a repertoire of figures capable of satisfying the need that has originated precisely from that emptiness" (Giglioli 2014: 9-10). Compassion invests the image with meanings, making the subject's reality - which has no constructs but experience only seem to the third party like the reality of a victim. The same thing happens with the conviction of a tormentor. A tormentor's personal (everyday) reality is portrayed as specifically belonging to the tormentor.

On the other hand, the "theatre of forgiveness" (Jacques Derrida uses this term regarding the contemporary phenomenon of total repentances) became the way of self-constructing the image of a tormentor. The totality (globality) of this repentance strategy ensures a symbolic positive balance of the third party, giving it a role of a generous judge. Such a presumption about the third party raises its status, but it would be impossible without the geopolitics of repentance, realised in the "theatre of forgiveness" (Derrida 2000). ${ }^{6}$

Moreover, both the victim and the tormentor must be absolutely sterile, i.e., their negativity must not impinge upon the positivity of the subject, i.e., they must be spatially localized. Space is delineated into zones in which the positive subject is constructed, and into others in which the subject is negative; what is more, it is not important in what sense - the ethically bad (the tormentor) or the depleted (indebted) (the victim). In this way, a spatial segregation is created: the place of the trauma as one of negative victimal balance, the place of the victim as one of zero victimal balance, and the place of positive balance.

Those who do not exploit it directly and in their own name do so by proxy. There is no lack of middlemen, who take their financial or symbolic cut in the process. Deficit and misfortune, like the international debt, are traded 
and sold on in the speculative market - in this case the politico-intellectual market, which is quite the equal of the late, unlamented military-industrial complex. (Baudrillard 1996: 135)

The victim is localized in a way that it is in any case evaluated as Other-weak (the opposite of Other-strong (Troitskiy 2011)), i.e., it cannot leave the space ${ }^{7}$ of its coexistence with its tormentor, the space where the victim and the tormentor are forever bound together, representing a peculiar transformation of the dialectic of Slave and Master from Hegel's The Phenomenology of Spirit (Hegel 2018), or Baudrillard's dialectic of Good and Evil. ${ }^{8}$ In this sense the localisation of the victim differs little in terms of the means of spatial fixation from the Russian Empire's pale of settlement or the Jewish ghettoes created by the Nazis. Direct participation in such a localisation automatically puts the participant into the category of tormentor, providing a possibility for the exchange of roles in this dialectic union. ${ }^{9}$ However, it is this very third party, not included in the victim-tormentor relationship, and not even considered by Hegel, which reaps the profit in the form of symbolic capital. ${ }^{10}$ The third party reaps the absolute profit in the form of a public execution: the victim loses something and the executor pays by losing a symbolic (sacral) purity, while the third party kills the perpetrator with another person's hands, educating and evoking compassion. In a global world every subject must take one of the three parties. Admitting being a sacrifice and accepting their own victimhood allows the third party to take back part of the profit in the form of a humanitarian mission, compassion, help, etc. So, "the victims themselves ... get the benefit of confessing their misery" (Baudrillard 1996: 138), although the benefit looks suspicious because, in fact, it is only a partial compensation for the symbolic capital. The world needs zones of debt (minus), zones of victimhood, because without them it is impossible to support a positive balance of sympathy, kindness, and morality. In compliance with the victim economy, political discourses are built around all current international conflicts (in Syria, the Donbass region, and others). The global world is interpreted as a unified space where the laws of humanism hold sway. However, for the victim economy humanism is more valuable than empathy, as it can bring dividends. As a result of the race for humanism, greater symbolic capital can be accrued by anyone who can distribute their price of humanism among most supporters and the largest quantity of subjects, even if they do that using bombers and ballistic missiles. When expressed in the terminology of the victim economy, the level of a positive balance is directly dependent upon the number of subjects which are included in that price group. Even the decision to abolish the death penalty, or to impose a moratorium upon it, is argued over, using the same victimal logic and terminology: the state refuses to 
take on the role of the executor so as not to make another tormentor its victim, and so that the state can become separate from the dialectical relationship of victim and tormentor.

Due to the victim economy, topographical segregation into regions with a positive balance and regions with a negative balance is registered in the cultural reputation of these regions. Thus, a topographical hierarchy (a hierarchy of the preferences of topoi) is created (Troitskiy 2019). One of the prerequisites for this preference is a positive victimal balance. This also explains the choice of destinations for emigration. It explains why migration flows are directed towards certain regions and not towards some others. Moreover, for the contemporary distribution of functions within the victim economy there exists the presumption of the impenetrability of the borders between regions with a positive balance whereas those with a negative balance are impenetrable. In this regard, there is genuine surprise in both political discourse and at the level of ordinary consciousness at the fact that victims (subjects with a negative balance) can penetrate into space where the victimal balance is positive.

However, it appears that the victim order can be destroyed if the victim rejects the sacrifice status, suggesting compensation for damages. Then a conditional "sacrifice" takes the character of a trauma, and the subject of the trauma looks for a contribution. Class struggle and revolution (Kapelchuk 2016), terror/ terrorism (Baudrillard 2003: 1-34) and partisan movement become ways to compensate for damages. The subject of a trauma has a negative balance and repays their debts not with the usual payment instrument in the victim economy i.e., force (because they are weak) - but by discrediting a certain debtor's local payment instrument, discrediting a certain subject who has a debt (the police is powerless against terrorists, the army is powerless against partisans, the gendarmerie is powerless against underground fighters, etc.). However, while trying to discredit the instrumentality of force, the subject can use the same payment instrument (force) and, therefore, become the tormentor. By that the subject inverses roles inside the victim-tormentor pair; thus, the whole payment system becomes discredited because there is "no possible distinction between the 'crime' and the crackdown" (Baudrillard 2003: 31). In this sense, the roles are liquid inside the pair (Bauman \& Donskis 2016) and easily transform into one another. Here a trauma is understood as unaccepted loss. It is logical that the loci of economic life are the most preferable objects for discrediting the force. Then the concept of safety as a marker of the force's omnipotence in those loci is subject to devaluation and inflation. As a result, "in many urban commercial spaces, capitalism and terrorism as the most powerful discursive forces of contemporary culture - the most mainstream and the most extreme - meet in increasingly militarized urban space" (Mirgani 2017: 10). 
This circulation of the symbolic victim capital stimulates itself: the more traumas there are, the more contributions (i.e., traumas for other subjects) are made. More and more subjects get involved in the circulation, spreading like a virus. (Baudrillard (2003) calls it "the spirit of terrorism", making a reference to Max Weber's "spirit of capitalism"). This self-stimulating victim economy conforms to the Keynesian economics model where individual profligacy together with consumer and market activity are the main driving forces of the economy in general. The circulation also stimulates an increase in the price (in the case of the victim economy it is the price of trauma) not because of the increase in the uniqueness of goods but because of the inflation of values. It is contrary to the monetarist model where the subject's thrift influences the object's value. Cultural stereotypes of a traditional society resulted in the monetarist economics model. It is characteristic of the early-stage capitalism although it is realised normally as one of the subject's economical behaviour strategies; in the victim economy it is based on the latency of the subject's traumatic experience and sacrifice enforced by Abrahamic religions (Christianity, Judaism, Islam).

\section{CONCLUSION}

This paper provided a general description of the victim economy. Contrary to traumatic experience, the trauma construct is a result of meaning interpretation, comprehension, and accents. The victim economy uses techniques of constructing cultural phenomena (i.e., thinking or speaking). The concept and the construct of loss contain all characteristics and principles of conceptualisation and construction typical of other key cultural mechanisms. Constructs of loss, victim, and trauma constitute elements of the victim economy. The victim economy as the basis for the victim order is built on the principle of debt between the subjects. It corresponds to the contemporary economics model based on consumers' activity. Causing a trauma is interpreted as causing damage, so the term "loss" seems to be the most appropriate way to describe it. A starting point for building relationships is a presumption that a victim accepts becoming a victim and agrees to incur symbolic damage in the form of traumatic experience. The construct implies two acting parties: the first one is a victim and the second one is a party which is not usually taken into account because it is this party who actually considers the situation. A tormentor who caused damage is not considered an acting party; it exists as a sublated (Aufheben) non-acting subject. However, in case the role of a victim is unaccepted and the loss is final, loss-victim transforms into loss-trauma and the victim of this loss starts looking for an opportunity to repair the damage. Then the tormentor becomes an acting 
party who is an object of a symbolic lawsuit where the third party assumes the functions of a judge. It is very important that all the parties construct trauma in their own way; therefore, the roles and accents in those constructs depend on the party. As a result, there is a possibility that roles might switch in the course of a symbolic lawsuit.

\section{ACKNOWLEDGEMENTS}

The research was conducted as part of the research project No. 18-011-00570A with the financial support of the RFBR.

\section{NOTES}

1 Natalia Artemenko believes that "matrix texts" pose a problem for researchers (Artemenko 2020). Alexander Filyushkin in his book Metodicheskie ukazaniia po provedeniiu issledovanii po ustnoi istorii [Guidelines for conducting research on oral history] notes, "The problem of so-called 'matrix texts' [is] when a respondent passes a standard, almost official text known by the respondent for a personal opinion, feeling or experience, mistaking it for his/her own. ... A part of memoirs written about the Russian Revolution and the Civil War were, in fact, based on later films about these events (for example, Chapaev, Lenin in October). Moreover, replacement of personal memories with a foreign and unreliable 'matrix text' in the consciousness happened so long ago that the respondent is not always able to understand that he/she is simply broadcasting a point of view that was once imposed on the respondent from the outside" (Filyushkin 2004: 6).

${ }^{2}$ For example, dark tourism (Kidron 2012; 2013), commemorative practices (Hutton 1993), lieux de mémoire (Nora 1989), souvenirs as portative lieux de mémoire (Kidron 2012).

3 This mechanism was analysed and described by Alexander Brodsky (Brodsky 2015a, 2015b).

${ }^{4}$ In this sense it is not surprising how easily traumatic discourse can be commercialised.

5 The tormentor (executor) exists inside personal everyday life when they cause a trauma to someone (Harrington 2013).

6 According to Derrida, the "theatre of forgiveness" makes possible a discourse of the "crime against humanity", where humanity indicts humanity, i.e., itself. It reduces the importance and value of the crime because the criminal's (former executor's and tormentor's) guilt - as well as the guilt of everybody who aids or abets them by tacit connivance - is nullified by the referee's generosity. In this discourse the executor, the referee, the victim, and the criminal (former tormentor and executor) become the same collective subject, leading to a symbolic fraud which is self-forgiveness. In his other work, Derrida develops this thought, claiming that "forgiveness forgives only the unforgivable", it forgives the worst crimes, people, and absolute evil without any extenuating circumstances (Derrida 2001: 32). 
7 There is no difference whether the space is physical or symbolic, virtual or real.

8 "No one seems to have understood that Good and Evil advance together, as part of the same movement. The triumph of the one does not eclipse the other - far from it. In metaphysical terms, Evil is regarded as an accidental mishap, but this axiom, from which all the Manichaean forms of the struggle of Good against Evil derive, is illusory. Good does not conquer Evil, nor indeed does the reverse happen: they arc at once both irreducible to each other and inextricably interrelated. Ultimately, Good could thwart Evil only by ceasing to be Good since, by seizing for itself a global monopoly of power, it gives rise, by that very act, to a blowback of a proportionate violence" (Baudrillard 2003: 13-14).

9 For example, Stockholm syndrome. See also Artemenko 2018.

${ }^{10}$ However, Baudrillard, who clearly grasped the essence of the victim dialectic, suggests taking place of a third party and looking "beyond Good and Evil". It was a way to remove the blinders and to refuse the absolutisation of ethics for Nietzsche, but in fact, it legalised nonparticipant observation, viewer-researcher's point of view that is allegedly non-included, and the position of a referee and a guru. So, Baudrillard, who has given in to the temptations of the third party, explains the totality of Evil through the ontological pair of Good and Evil. At the same time, he either attributes unity to this pair (the first one grows if the second one does too) or remembers about the energy conservation law (if the first one loses, the second one receives).

\section{REFERENCES}

Alexander, Jeffrey C. \& Eyerman, Ron \& Giesen, Bernard \& Smelser, Neil J. \& Sztompka, Piotr 2004. Cultural Trauma and Collective Identity. Berkeley \& Los Angeles \& London: University of California Press.

Arango-Muñoz, Santiago \& Michaelian, Kourken 2020. From Collective Memory ... to Collective Metamemory? In: A. Fiebich (ed.) Minimal Cooperation and Shared Agency. Cham: Springer International Publishing, pp. 195-217.

Artemenko, Natalia 2018. Cataleptic Consciousness. Rivista di Estetica, Vol. 67, anno LVIII, pp.136-149. https://doi.org/10.4000/estetica.2720.

Artemenko, Natalia 2020. Ustnaia istoriia i problema "dostupa" k travmaticheskomu opytu. [Oral History and the Problem of "Access" to Traumatic Experience.] In: N. Artemenko (ed.) Topologiia travmy: Individual'nyi travmaticheskii opyt $i$ opyt istoricheskikh katastrof. Saint Petersburg: Renome, pp. 59-69.

Assmann, Aleida 2006. Der lange Schatten der Vergangenheit: Erinnerungskultur und Geschichtspolitik. Munich: C.H. Beck.

Barash, Jeffrey A. 2017. Collective Memory. In: S. Bernecker \& K. Michaelian (eds.) The Routledge Handbook of Philosophy of Memory. London \& New York: Routledge, pp. 255-267.

Baudrillard, Jean 1996. The New Victim Order. In: J. Baudrillard. The Perfect Crime. Transl. by Chris Turner. London \& New York: Verso, pp. 131-141.

Baudrillard, Jean 2003. The Spirit of Terrorism. Transl. by Chris Turner. London \& New York: Verso. 
Bauman, Zygmunt \& Donskis, Leonidas 2016. Liquid Evil. Cambridge: Polity.

Brodsky 2015a = Brodskii, Aleksandr. Travma i konstruktsiia $\mathrm{v}$ natsional'nom samosoznanii: Na materiale istorii vostochnoevropeiskikh evreev kontsa XIX nachala XX veka. [Trauma and Construction in National Consciousness: Based on the History of Eastern European Jews of the Late 19th - Early 20th Century.] Filosofiia $i$ kul'tura, Vol. 12, pp. 1783-1793. https://doi.org/10.7256/19992793.2015.12.15885.

Brodsky 2015b = Brodskii, Aleksandr. Kto vzoidet na goru Gospodniu? Pol'sha, Rossiia i Ukraina v svete messianskoi idei. [Who Shall Ascend the Hill of the Lord? Poland, Russia and Ukraine in the Light of Messianic Ideas.] VECHE: Zhurnal russkoi filosofi i kul'tury, Vol. 27, No. 1, pp. 185-208. Available at http://philosophy.spbu. ru/userfiles/rusphil/27-1-17.pdf, last accessed on 3 May 2021.

Brodsky 2020 = Brodskii, Aleksandr. Kreativnoe vytesnenie (k metodologii izucheniia kul'turnykh travm). [Creative Exclusion: On the Methodology of Studying Cultural Traumas.] In: N. Artemenko (ed.) Topologiia travmy: Individual'nyi travmaticheskii opyt $i$ opyt istoricheskikh katastrof. Saint Petersburg: Renome, pp. 19-34.

Butler, Gary R. 1992. Indexicality, Authority, and Communication in Traditional Narrative Discourse. The Journal of American Folklore, Vol. 105, No. 415, pp. 3456. http://dx.doi.org/10.2307/541998.

Caruth, Cathy (ed.) 1995. Trauma: Explorations in Memory. Baltimore \& London: The Johns Hopkins University Press.

Chertenko, Alexander \& Nikolaeva, Zhanna \& Troitskiy, Sergey (eds.) 2018. Rivista di Estetica, Vol. 67. Special Issue: Cultural Exclusion and Frontier Zones. https:// doi.org/10.4000/estetica.2433.

Derrida, Jacques 2000. La mondialisation, la paix et la cosmopolitique. Regards, Vol. 54, pp. 16-19. Available at http://www.regards.fr/archives/archives-web/lamondialisation-la-paix-et-la,1806, last accessed on 3 May 2021.

Derrida, Jacques 2001. On Cosmopolitanism and Forgiveness. Transl. by Mark Dooley \& Michael Hughes. London \& New York: Routledge.

Filyushkin 2004 = Filiushkin, Aleksandr. Metodicheskie ukazaniia po provedeniiu issledovanii po ustnoi istorii. [Guidelines for Conducting Research on Oral History.] Saint Petersburg: Izd-vo SPbGPU.

Giglioli, Daniele 2014. Critica della vittima: Un esperimento con l'etica. Roma: Nottetempo.

Halbwachs, Maurice 1992. On Collective Memory. Edited and translated by Lewis A. Coser. Chicago \& London: The University of Chicago Press.

Harrington, Joel F. 2013. The Faithful Executioner: Life and Death, Honor and Shame in the Turbulent Sixteenth Century. New York: Farrar, Straus \& Giroux.

Hegel, Georg W.F. 2018. The Phenomenology of Spirit. Transl. by Michael Inwood. Oxford: Oxford University Press.

Hirschberger, Gilad 2018. Collective Trauma and the Social Construction of Meaning. Frontiers in Psychology, Vol. 9, art. 1441. http://dx.doi.org/10.3389/ fpsyg.2018.01441.

Hirst, William \& Echterhoff, Gerald 2008. Creating Shared Memories in Conversation: Toward a Psychology of Collective Memory. Social Research, Vol. 75, No. 1, pp. 183216. Available at https://www.jstor.org/stable/40972057, last accessed on 3 May 2021.

Hutton, Patrick H. 1993. History as an Art of Memory. Hanover: University Press of New England. 
Jackson, Bruce 2007. The Story Is True: The Art and Meaning of Telling Stories. Philadelphia: Temple University Press.

Kapelchuk, Ksenia 2016. K genealogii ugnetennogo: marksizm i diskurs zhertvy. [To the Genealogy of the Oppressed: Marxism and the Discourse of the Victim.] Neprikosnovennyi zapas: Debaty o politike i kul'ture, Vol. 5, No. 109, pp. 146-163. Available at https://www.nlobooks.ru/magazines/neprikosnovennyy_zapas/109_nz_5_2016/ article/12127/, last accessed on 3 May 2021.

Kidron, Carol A. 2003. Surviving a Distant Past: A Case Study of the Cultural Construction of Trauma Descendant Identity. Ethos, Vol. 31, No. 4, pp. 513-544. http:// dx.doi.org/10.1525/eth.2003.31.4.513.

Kidron, Carol A. 2012. Breaching the Wall of Traumatic Silence: Holocaust Survivor and Descendant Person-Object Relations and the Material Transmission of the Genocidal Past. Journal of Material Culture, Vol. 17, No. 1, pp. 3-21. http://dx.doi. org/10.1177/1359183511432989.

Kidron, Carol A. 2013. Being There Together: Dark Family Tourism and the Emotive Experience of Co-presence in the Holocaust Past. Annals of Tourism Research, Vol. 41, pp. 175-194. http://dx.doi.org/10.1016/j.annals.2012.12.009.

LaCapra, Dominick 1994. Representing the Holocaust: History, Theory, Trauma. Ithaca \& London: Cornell University Press.

Lekhtsier, Vitaly 2018. Bolezn':opyt, narrativ, nadezhda. Ocherk sotsial'nykh igumanitarnykh issledovanii meditsiny. [Illness: Experience, Narrative, Hope. Essay on Social and Humanitarian Research of Medicine.] Vilnius: Logvino literatūros namai.

Maslinskaia, Svetlana 2019. Nasilie i travma v detskoi literature 1941-1945 godov. [Violence and Trauma in the Children's Literature of 1941-1945.] Russkaia literatura, Vol. 2, pp. 194-203. Available at https://ras.jes.su/rusliter/ issue.2019.2.2-ru-2-3, last accessed on 3 May 2021.

Mirgani, Suzi 2017. Target Markets - International Terrorism Meets Global Capitalism in the Mall. Bielefeld: Transcript Verlag.

Mould, Tom 2011. A Backdoor into Performance. In: R. Cashman \& T. Mould \& P. Shukla (eds.) The Individual and Tradition: Folkloristic Perspectives. Special Publications of the Folklore Institute No. 8. Bloomington \& Indianapolis: Indiana University Press, pp. 127-143.

Niethammer 2014 = Nitkhammer, Lutts. Seminar "Teoreticheskie i prakticheskie aspekty ustnoi istorii" s Luttsem Nitkhammerom. [Seminar "Theoretical and Practical Aspects of Oral History" with Lutz Niethammer.] Urokiistorii.ru, 4 February. Available at https://urokiistorii.ru/article/52024, last accessed on 29 April 2021.

Nora, Pierre 1989. Between Memory and History: Les Lieux de Mémoire. Representations, Vol. 26. Special Issue: Memory and Counter-Memory, pp. 7-24. https://doi. org/10.2307/2928520.

Olick, Jeffrey K. \& Vinitzky-Seroussi, Vered \& Levy, Daniel 2011. The Collective Memory Reader. New York: Oxford University Press.

Oushakine 2009 = Ushakin, Sergei 2009. "Nam etoi bol'iu dyshat'?" O travme, pamiati i soobshchestvakh. [“Should We Breathe This Pain?": On Trauma, Memory and Communities.] In: S. Ushakin \& E. Trubina (eds.) Travma: Punkty. Moscow: Novoe literaturnoe obozrenie, pp. 5-41. Available at https://scholar.princeton.edu/ sites/default/files/oushakine/files/190-2039942.pdf, last accessed on 3 May 2021.

Oushakine \& Trubina $2009=$ Ushakin, Sergei \& Trubina, Elena (eds.) 2009. Travma: Punkty. [Trauma: Points.] Moscow: Novoe literaturnoe obozrenie. 
Resende, Erica \& Budryte, Dovile (eds.) 2014. Memory and Trauma in International Relations: Theories, Cases and Debates. London \& New York: Routledge.

Savchuk, Valerii 2020. Krov'i kul'tura. [Blood and Culture.] Saint Petersburg: Akademiia issledovaniia kul'tury.

Sidorov, Alexey 2020. Obzor literatury po teorii kul'turnoi travmy. [Review of Literature on Theory of Cultural Trauma.] In: N. Artemenko (ed.) Topologiia travmy: Individual'nyi travmaticheskii opyt i opyt istoricheskikh katastrof. Saint Petersburg: Renome, pp. 232-245.

Stone, Charles B. \& Coman, Alin \& Brown, Adam D. \& Koppel, Jonathan \& Hirst, William 2012. Toward a Science of Silence: The Consequences of Leaving a Memory Unsaid. Perspectives on Psychological Science, Vol. 7, No. 1, pp. 39-53. http:// dx.doi.org/10.1177/1745691611427303.

Tan, Sherman 2020. What is "Collective Memory"? Theories of Memory and Heritage: Social, Cultural, and Historical Perspectives. Online. Available at https://www. academia.edu/5244185/Collective_Memory, last accessed on 16 June 2021.

Troitskiy 2011 = Troitskii, Sergei. Obraz "chuzhogo-sil'nogo" v narodnoi kul'ture. [Image of the "Alien-Strong" in the Folk Culture.] VECHE: Zhurnal russkoi filosofii i kul'tury, Vol. 22, pp. 224-231. Available at http://philosophy.spbu.ru/ rusphil/1405/8737/7552, last accessed on 3 May 2021.

Troitskiy 2017 = Troitskii, Sergei. Sintaksis utraty. [Syntax of the Loss.] Studia Culturae, Vol. 2 (32), pp. 160-172. Available at http://iculture.spb.ru/index.php/stucult/ issue/view/43/showToc, last accessed on 3 May 2021.

Troitskiy, Sergey 2018. The Problem of Terminological Precision in Studies on Cultural Exclusion Zones. Rivista di Estetica, No. 67, pp. 165-180. https://doi.org/10.4000/ estetica.2772.

Troitskiy 2019 = Troitskii, Sergei. Konstrukt travmy kak osnova dlia formirovaniia topograficheskoi ierarkhii. [Trauma Construct as a Basis for Forming a Topographical Hierarchy.] Neprikosnovennyi zapas: Debaty o politike i kul'ture, Vol. 1, No. 123, pp. 123-131. Available at https://www.nlobooks.ru/magazines/ neprikosnovennyy_zapas/123_nz_1_2019/, last accessed on 3 May 2021.

Tulli, Magdalena 2011. Bronek. In: M. Tulli. Wtoskie szpilki. [Italian High Heels.] Warszawa: Nisza, pp. 63-78.

Vignoles, Vivian \& Regalia, Camillo \& Manzi, Claudia \& Golledge, Jen \& Scabini, Eugenia 2006. Beyond Self-esteem: Influence of Multiple Motives on Identity Construction. Journal of Personality and Social Psychology, Vol. 90, No. 2, pp. 308-333. http://dx.doi.org/10.1037/0022-3514.90.2.308.

Willsey, Kristiana 2015. Falling Out of Performance: Pragmatic Breakdown in Veterans' Story-telling. In: T.J. Blank \& A. Kitta (eds.) Diagnosing Folklore: Perspectives on Disability, Health, and Trauma. Jackson, MS: University Press of Mississippi, pp. 215-232.

Sergey Troitskiy is Senior Research Fellow at the Herzen State Pedagogical University of Russia. His main research areas are theory of cultural exclusion and frontier zones, trauma and memory studies, methodology of cultural studies in perspectives of Russian philosophy.

sergtroy@yandex.ru 